\title{
Intense localized rock uplift and erosion in the St Elias orogen of Alaska
}

\author{
E. Enkelmann ${ }^{1 \star}$, P. K. Zeitler ${ }^{1}$, T. L. Pavlis ${ }^{2}$, J. I. Garver ${ }^{3}$ and K. D. Ridgway ${ }^{4}$
}

The timing and role of exhumation in the St Elias orogen, the world's highest coastal mountain range, has been unclear. Sampling is limited to high mountain ridges that tower over widespread ice fields that sit in deeply eroded parts of the orogen. Existing bedrock studies ${ }^{1-3}$ in the region are therefore prone to bias. Here we analyse detrital material of active sediment systems in the St Elias orogen to obtain age information from the inaccessible ice-covered valley bottoms. We present 1,674 detrital zircon fission-track ages from modern rivers that drain the glaciers. We find a population of very young ages of less than 3 Myr from the Seward-Malaspina glacier systems that is sharply localized in the area of the orogen's highest relief, highest seismicity and at the transition from transform to subduction tectonics. Our data provide evidence for intense localized exhumation that is driven by coupling between erosion and active tectonic rock uplift.

The St Elias mountain belt originates from the collision of the Yakutat terrane with North America, at the corner formed by the dextral Fairweather transform and the Aleutian subduction zone (Fig. 1). Initiation of the Fairweather fault and northward transport of the Yakutat terrane started $\sim 30$ Myr ago, but collision began at $10-5 \mathrm{Myr}$ as the thickened crust of the Yakutat terrane accreted to the Aleutian trench ${ }^{4,5}$, stripping sedimentary cover from basement to construct a foreland fold and thrust belt ${ }^{4,6}$ (Fig. 2). Along the orogenic belt, the youngest (5-0.5 Myr) low-temperature cooling ages of bedrock $\left(60-110^{\circ} \mathrm{C}\right.$ closure temperatures $\left(T_{\mathrm{c}}\right)$ for apatite (U-Th)/He (ref. 7) and fission $\operatorname{track}^{8}$ ) are strongly correlated with those areas with the highest precipitation along the southern, seaward flanks of the orogen. Bedrock cooling ages are oldest (40-8 Myr) in the drier northern side ${ }^{1,2}$ (Fig. 2). Bedrock zircon fission-track (ZFT) ages $\left(T_{\mathrm{c}} \sim 250^{\circ} \mathrm{C}\right.$; ref. 9$)$ give $>10 \mathrm{Myr}$ ages ${ }^{3,10}$ (Fig. 2), or are non-reset in the fold-thrust belt, because lateral transport of material into the orogenic wedge results in exhumation restricted to the upper $5 \mathrm{~km}$ (ref. 10).

Similar to other active orogenic belts with high erosion rates, the St Elias range seems to have developed localized feedback between erosion and crustal strain ${ }^{11-13}$. Thus, it is puzzling that no evidence has emerged for locally enhanced exhumation and erosion in the form of localized young, higher-temperature cooling ages. However, the St Elias orogen is unique among active orogens in that more than $50 \%$ of its area is covered by glaciers hundreds of metres in thickness (Fig. 2). Besides reducing bedrock exposures in general, this glaciation also prohibits direct sampling of the low-elevation intensely glaciated valley bottoms where the most recently exhumed rocks and youngest cooling ages would be expected.

To overcome this sampling obstacle, we analysed detrital zircons from rivers draining the main glacial systems to evaluate the cooling

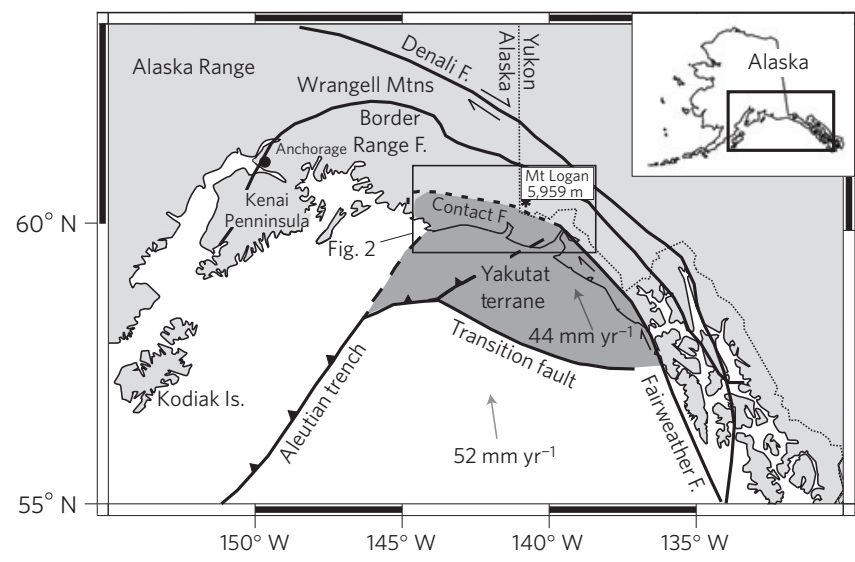

Figure 1 | Tectonic map of southern Alaska. Plate motion vectors are from ref. 29.

ages of these young exhumed parts of the orogen (Fig. 2). This approach was successful in a study of samples collected from the area north of the Bagley Ice field, where the previously unknown older exhumation history was revealed ${ }^{14}$ (Fig. 2). We applied the same approach to the glacial drainages along the southern side of the orogen (Fig. 2; Supplementary Table S1).

Detrital fission-track age distributions from single zircons are shown in pie charts (Fig. 2). The key finding is that samples from the Seward-Malaspina glacier have a significant fraction of ZFT ages of $<3 \mathrm{Myr}$, whereas samples farther west have increasingly larger percentages of older ages $(>6 \mathrm{Myr})$. Analysis of these data using binomial peak-fitting routines ${ }^{15}$ yields age populations for each sample. A remarkable aspect of the cooling ages in the Seward-Malaspina samples is that single-grain ZFT ages are as young as $0.4 \mathrm{Myr}$ and define an age-population peak at 2-3 Myr that comprises $25-41 \%$ of the dated grains. Laser-ablation inductively coupled plasma mass spectrometry $\mathrm{U} / \mathrm{Pb}$ ages of all detrital zircons that yielded ZFT ages of $<15 \mathrm{Myr}$ (samples I3 and I4) show that these zircons crystallized at 100-50 Myr, indicating that the ZFT ages are the result of cooling due to exhumation and not local volcanic activity (Fig. 3; Supplementary Table S2).

The young detrital zircons were transported by an unusual glacial system that begins in the core of the highest part of the St Elias orogen (red shaded area in Fig. 2). The upper part of this system is the Seward Glacier, which flows seaward through a narrow $(3-4 \mathrm{~km}), 2-3-\mathrm{km}$-deep gorge with fast-moving ice ${ }^{16}$ $\left(1,600 \mathrm{~m} \mathrm{yr}^{-1}\right)$, known as the Seward throat. When the ice emerges from the Seward throat, it spreads onto a flat plain to form

\footnotetext{
${ }^{1}$ Earth and Environmental Science, Lehigh University, 31 Williams Dr., Bethlehem, Pennsylvania 18015, USA, ${ }^{2}$ Department of Geological Sciences, University of Texas at El Paso, 500 West University Ave., El Paso, Texas 79968, USA, ${ }^{3}$ Department of Geology, Union College, 807 Union St., Schenectady, New York 12308-2311, USA, ${ }^{4}$ Department of Earth and Atmospheric Sciences, Purdue University, 550 Stadium Mall Dr., West Lafayette, Indiana 47907, USA. *e-mail: eva.enkelmann@lehigh.edu.
} 


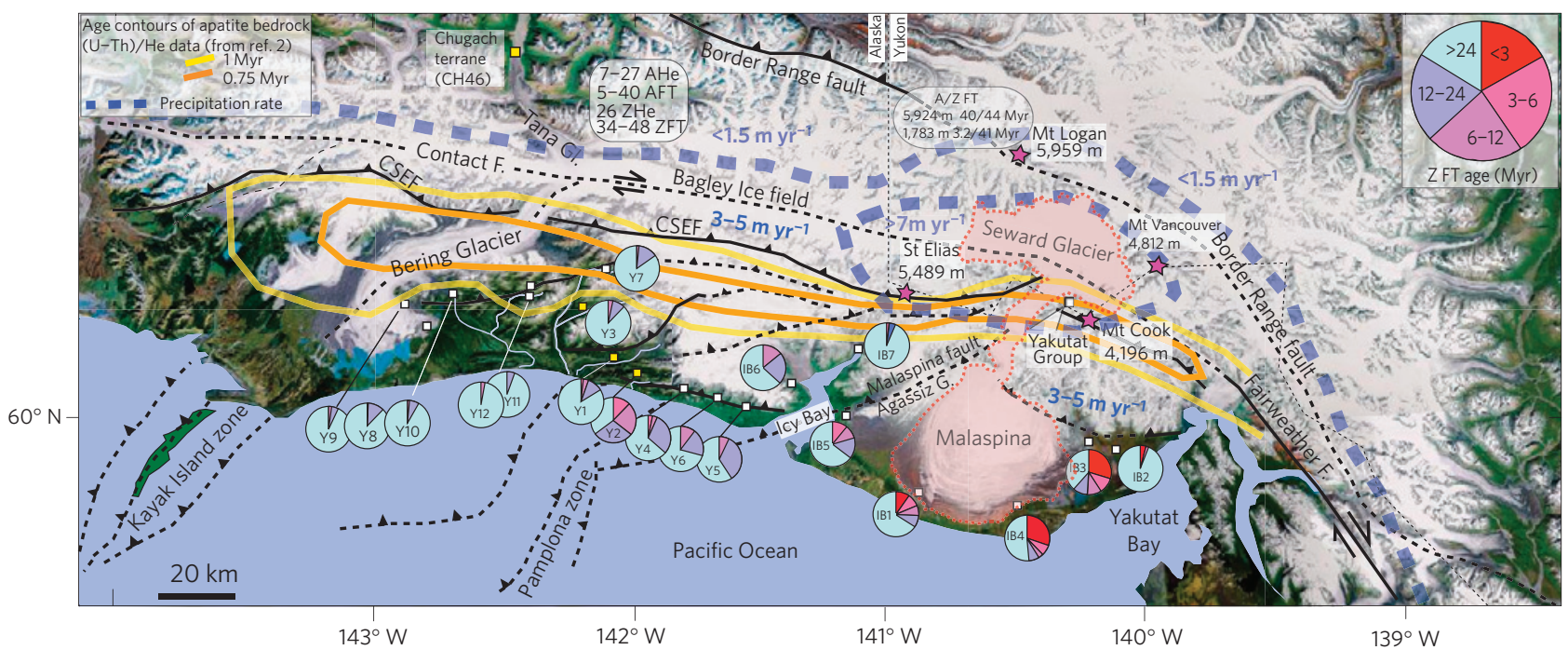

Figure 2 | Sample locations and main tectonic structures. Samples Y1, Y2, Y3 and CH46 were published in Enkelmann et al. ${ }^{14}$. CSEF: Chugach/St Elias fault, separating the Yakutat terrane from the Prince William terrane. The Contact fault sutures the Prince William from the Chugach terrane, and the Border Range fault sutures the Chugach (south) from the Wrangellia terrane (north). The drainage area of the Seward-Malaspina glacier is outlined in red. Thermochronological ages from bedrock studies are shown ${ }^{1-3,10}$. AHe: apatite (U-Th)/He, AFT: apatite fission track, ZHe: zircon (U-Th)/He, ZFT: zircon fission-track.

the Malaspina Glacier. Sediments in a glacial drainage can be transported parallel to each other and mix less than in fluvial systems. In addition, cooling ages from a detrital sample give an average of mainly the low-elevation part of the drainage basin that is covered by ice. This feature allows much greater insight into specific source rocks. The samples with the young ZFT ages (IB1 to IB4) lie within the part of the Malaspina lobe that originates from the Seward Glacier catchment, indicating that all of the young ages originate from the Seward Glacier, the Seward throat, or both. On the other hand, sample IB5 (Fig. 2) is from the Malaspina Glacier, but the ice mass feeding that specific site is the Agassiz Glacier, which originates from the south face of Mount St Elias. In this case, the lack of very young ZFT ages indicates that rapidly exhuming rocks do not occur in this part of the orogen. This finding is crucial because all young ( $<2 \mathrm{Myr}$ ) bedrock apatite (U-Th)/He ages seen so far are from this zone $e^{1,2}$ (Fig. 2).

To further refine the source rock identity for the young detrital ZFT ages, we compared the U/Pb zircon crystallization ages of samples IB3 and IB4 with samples from potential source areas. The $\mathrm{U} / \mathrm{Pb}$ ages of sample IB4 show a distinct population of $60-50 \mathrm{Myr}$ similar to the detrital grains from sediments of the Tana Glacier ${ }^{14}$ draining the Bagley Ice field towards the northwest (Figs 2 and 3). The drainage area of the Bagley Ice field and the western Seward Glacier consists of rocks of the Early Eocene Chugach metamorphic complex $^{17,18}$. In contrast, IB3 shows a distinctly different detrital signature with a prominent population of 100-90 Myr absent in rocks of the Chugach metamorphic complex, but similar to detrital zircons obtained in bedrock exposures of the Yakutat Group (Figs 2 and 3; Supplementary Table S3). This comparison is important because collectively these results suggest that the young ZFT ages are all derived in the upper Seward Glacier catchment, and the Seward throat is probably not a large contributor because this segment of the glacier flows almost exclusively on bedrock of the Yakutat Group.

The upper Seward Glacier is part of a large, linear ice field that extends across the interior of the orogen with drainage divides between the highest peaks of the orogen (Fig. 2). The western arm of this ice field, the Bagley Ice field, flows westward to feed the bulk of the Bering Glacier and part of the Tana Glacier, yet there is no significant difference between the underlying geology

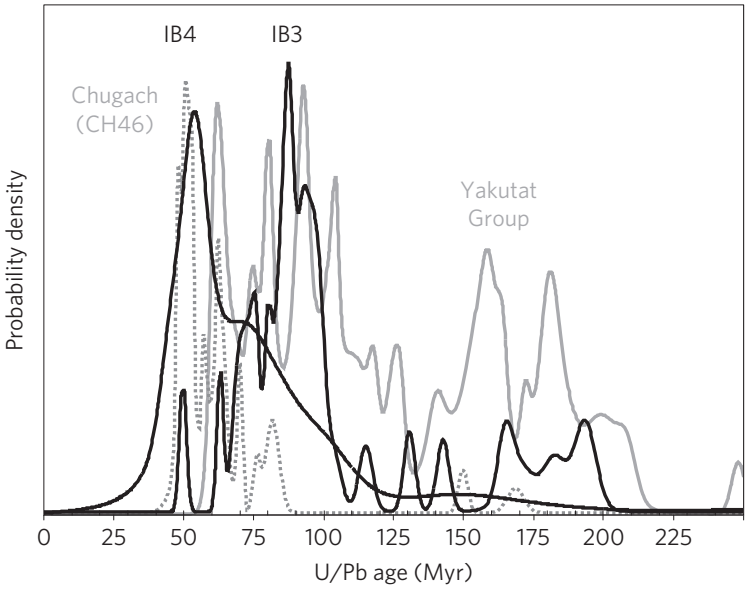

Figure 3 | Comparison of $\mathbf{U} / \mathbf{P b}$ zircon ages. Probability density plots of $\mathrm{U} / \mathrm{Pb}$ zircon ages of samples IB3 and IB4 compared with the zircon $\mathrm{U} / \mathrm{Pb}$ ages from sample $\mathrm{CH} 46$ (ref. 14) representing material of the Chugach metamorphic complex that was transported by the Bagley Ice field/Tana glaciers system (Fig. 2), and the detrital zircon results of the Yakutat Group sample dated for this study (see Supplementary Table S3). The Yakutat Group is the metasedimentary basement of the Yakutat terrane.

between the Bagley and upper Seward Glaciers. Both glaciers follow an Eocene suture, the Contact fault that was reactivated as the westward continuation of the Fairweather transform during Yakutat collision ${ }^{6}$. Although the Bering Glacier is similar in size to the Malaspina, samples from the Bering Glacier yield ZFT cooling ages that are $>14 \mathrm{Myr}$, much older than those from the Malaspina (Fig. 2).

The location of the upper Seward Glacier coincides with the orogenic 'corner' where the dextral strike-slip system merges with the fully convergent core of the orogen. The location of the Seward-Malaspina glacier also follows the Malaspina fault, the eastern continuation of the offshore Pamplona zone ${ }^{6,17}$ (Fig. 2). The Pamplona zone is the easternmost edge of the Aleutian megathrust and the current deformational front $t^{6,17}$, which is also supported by global positioning system measurements showing the largest 
amount of convergence across this fault ${ }^{19}$. The entire area below the Seward Glacier and western Malaspina Glacier also experiences the highest seismic activity in the region ${ }^{20}$. Similarly, the Bering Glacier coincides with the trend of the Kayak Island zone (Fig. 2), the former position of the Aleutian megathrust and deformational front ${ }^{17,20}$. This suggests that the local high topographic relief $(\sim 5,000 \mathrm{~m})$ and locally fast exhumation underneath the Seward Glacier is partly driven by active faulting.

The geodynamic significance of this localization of young ages derives from the closure behaviour of fission tracks in these samples and what this in turn suggests for exhumational processes. The approximate closure temperature for fission tracks in zircon is $250 \pm 40^{\circ} \mathrm{C}$, depending on cooling rate and radiation damage ${ }^{10}$. However, zircons with very young fission-track ages tend to have little radiation damage and so have higher closure temperatures of $300-350^{\circ} \mathrm{C}$ (refs 21,22 ). Thermal structure in the St Elias orogen is likely to be complex and in a transient state, given the three dimensionality of the surface (mean elevation of $\sim 2,500 \mathrm{~m}$, with relief of up to $5,000 \mathrm{~m}$ ), and the complex thermal structure in the accreted terranes that make up the local basement. Nevertheless, it is possible to put conservative bracketing limits on depth of closure, provided we can estimate the geothermal gradient.

If the orogen has reached thermal steady state, then simple assumptions of a thermal gradient for the shallower crust can be used to estimate closure depth. Estimates for geothermal gradients for the general St Elias region range from 21 to $50{ }^{\circ} \mathrm{C} \mathrm{km}^{-1}$, and average about $35^{\circ} \mathrm{C} \mathrm{km}^{-1}$ (refs $1,3,23,24$ ). Using $300-350^{\circ} \mathrm{C}$ as the fast-cooling closure temperature for fission tracks in rapidly cooled zircon would lead to a closure-depth estimate of $8-10 \mathrm{~km}$. A one-dimensional thermal model ${ }^{9}$ that incorporates appropriate annealing kinetics suggests closure depths of $5-10 \mathrm{~km}$ for a wide range of crustal states, for zircons $2-3 \mathrm{Myr}$ in age. Although dependent on assumptions about boundary conditions, one-dimensional modelling of the transient case involving onset of rapid exhumation within the past few million years predicts closure depths as great or greater than those determined using steady-state assumptions. Finally, given that the source of our young zircons must be in the ice-covered valley bottoms of the Seward Glacier system, one needs to consider isotherm compression beneath valleys, resulting in lower depths of closure. All in all, we suggest $5-10 \mathrm{~km}$ as a reasonable minimum estimate for closure depth, pending better-constrained thermomechanical modelling.

Compared with low-temperature thermochronological results from apatite, which can be explained essentially entirely by variations in climate-controlled erosional processes acting over $5,000 \mathrm{~m}$ of relief, the young ZFT ages require differential and quite localized exhumation be underway in the Seward-Malaspina glacier system. Our data provide direct evidence that exhumation varies considerably along strike in the St Elias orogen, with locally greater degrees of exhumation occurring at rates comparable to those seen in the highly active Himalayan syntaxes ${ }^{12}$ or along the Alpine fault in New Zealand ${ }^{25}$. The upper Seward Glacier region may represent a 'tectonic aneurysm' analogous to features described in the eastern and western Himalayan syntaxes ${ }^{11,12}$ but heretofore not identified outside the terminations of the Himalayan chain (further discussed in Supplementary Information). In the aneurysm model, coupling occurs between localized crustal strain and focused erosion, with significant amounts of erosion leading to heat advection and weakening of the crust, localization and intensification of strain, and building of high relief, thus feeding back into continued rapid erosion. Owing to the shallower crustal levels involved in the St Elias range, and the fact that Yakutat collision is much younger (10-5 Myr) in comparison to the India-Asia collision ( $\sim 50 \mathrm{Myr})$, it is possible that the St Elias feature is younger and represents the nascent stage of this condition.

\section{Methods}

We sampled sand from rivers that drain glaciers and ice fields at the south side of the St Elias range. Generally, we sampled as close as possible to the glacier ice front, to obtain sediments transported by the main sub-glacial river. ZFT ages were measured at Union College following procedures described by Garver and Kamp ${ }^{26}$ and Garver ${ }^{27}$. We prepared 3-4 zircon mounts per sample. The polished mounts were etched for $20-30 \mathrm{~h}$ in a $\mathrm{KOH} / \mathrm{NaOH}$ eutectic solution at $228^{\circ} \mathrm{C}$ to reveal fossil tracks. Zircon mounts were then covered with a uranium-free muscovite external detector using the nuclear reactor at Oregon State University. The external detectors were etched in $48 \% \mathrm{HF}$ at room temperature for $18 \mathrm{~min}$ to reveal induced tracks. Tracks were counted using an automated stage and Olympus BH2 microscope at $\times 1,250$ magnification. The measured single grain-age distributions were deconvolved into component age populations using the binomial peak-fitting $\operatorname{method}^{28}$ (see Supplementary Table S1). For samples IB3 and IB4, the U/Pb age of individual zircon grains yielding young $(<15 \mathrm{Myr})$ fission-track ages was measured using laser-ablation inductively coupled plasma mass spectrometry at the University of Arizona. Pairs of ZFT and $\mathrm{U} / \mathrm{Pb}$ ages of individual grains are reported in Supplementary Tables S2 and S3, together with $100 \mathrm{U} / \mathrm{Pb}$ ages of single zircon from a bedrock sample of the Yakutat Group, representing the metasedimentary basement of the Yakutat terrane.

\section{Received 6 October 2008; accepted 25 March 2009;} published online 26 April 2009

\section{References}

1. Berger, A. L. et al. Architecture, kinematics, and exhumation of a convergent orogenic wedge; a thermochronological investigation of tectonic-climatic interactions within the central St. Elias Orogen, Alaska. Earth Planet. Sci. Lett. 270, 13-24 (2008)

2. Berger, A. L. \& Spotila, J. A. Denudation and deformation in a glaciated orogenic wedge: The St. Elias orogen, Alaska. Geology 36, 523-526 (2008).

3. O'Sullivan, P. B. \& Currie, L. D. Thermotectonic history of Mt Logan, Yukon Territory, Canada: Implications of multiple episodes of middle to late Cenozoic denudation. Earth Planet. Sci. Lett. 144, 251-261 (1996).

4. Plafker, G. in Geology and Resource Potential of the Continental Margin of Western North America and Adjacent Ocean Basins Vol. 6 (ed. Scholl, D. W.) 229-268 (Circum-Pacific Council for Energy and Mineral Resources, 1987).

5. Ferris, A., Abers, G. A., Christensen, D. H. \& Veenstra, E. High resolution image of the subducted Pacific plate beneath central Alaska, 50-150 km depth. Earth Planet. Sci. Lett. 214, 575-588 (2003).

6. Bruhn, R. L., Pavlis, T. L., Plafker, G. \& Serpa, L. Deformation during terrane accretion in the Saint Elias orogen, Alaska. Geol. Soc. Am. Bull. 116, 771-787 (2004).

7. Farley, K. A. Helium diffusion from apatite: General behaviour as illustrated by Durango fluorapatite. J. Geophys. Res. 105, 2903-2914 (2000).

8. Green, P. F., Duddy, I. R., Gleadow, A. J. W., Tingate, P. T. \& Laslett, G. M. Thermal annealing of fission tracks in apatite: $1-$ a qualitative description. Isot. Geosci. 59, 237-253 (1986).

9. Brandon, M. T., Roden-Tice, M. K. \& Garver, J. I. Late Cenozoic exhumation of the Cascadia accretionary wedge in the Olympic Mountains, northwest Washington State. Geol. Soc. Am. Bull. 110, 985-1009 (1998).

10. Meigs, A., Johnston, S., Garver, J. I. \& Spotila, J. A. Crustal-scale structural architecture, shortening, and exhumation of an active, eroding orogenic wedge (Chugach/St Elias Range, southern Alaska). Tectonics 27, TC4003 (2008).

11. Koons, P. O., Zeitler, P. K., Chamberlain, C. P., Craw, D. \& Meltzer, A. S. Mechanical links between erosion and metamorphism in Nanga Parbat, Pakistan Himalaya. Am. J. Sci. 302, 749-773 (2002).

12. Zeitler, P. K. et al. Crustal reworking at Nanga Parbat, Pakistan: Metamorphic consequences of thermal-mechanical coupling facilitated by erosion. Tectonics 20, 712-728 (2001).

13. Montgomery, D. R. \& Stolar, D. B. Reconsidering Himalayan river anticlines. Geomorphology 82, 4-15 (2006).

14. Enkelmann, E., Garver, J. I. \& Pavlis, T. L. Rapid exhumation of ice-covered rocks of the Chugach-St. Elias orogen, SE-Alaska. Geology 36, 915-918 (2008).

15. Bernet, M. \& Garver, J. I. Fission-track analysis of detrital zircon. Rev. Mineral. Geochem. 58, 205-237 (2005).

16. Headley, R., Hallet, B. \& Rignot, E. Measurements of fast ice flow of the Malaspina Glacier to explore connections between glacial erosion and crustal deformation in the St. Elias Mountains, Alaska. Eos Trans. AGU 88 C41A-0050 (2007).

17. Plafker, G., Moore, J. C. \& Winkler, G. R. in The Geology of Alaska. Geol. N. America Vol. G-1 (eds Plafker, G. \& Berg, H. C.) 389-449 (GSA, 1994).

18. Sisson, V. B. et al. in Geology of a Transpressional Orogen Developed During Ridge-Trench Interaction Along the North Pacific Margin (eds Sisson, V. B. et al.) 293-326 (Geological Society of America, 2003).

19. Elliott, J., Freymueller, J. T. \& Larsen, C. F. Collisional Tectonics in the St. Elias orogen, Alaska, observed by GPS. Eos Trans. AGU 89 Fall Meet. Suppl., Abstract T44A-04. (2008) 
20. Ruppert, N. A., Ridgway, K. D., Freymueller, J. T., Cross, R. S. \& Hansen, R. A. in Active Tectonics and Seismic Potential of Alaska (ed. Freymueller, J. T.) 109-133 (Geophysical Monograph Series, Vol. 179, American Geophysical Union, 2008).

21. Tagami, T., Galbraith, R. F., Yamada, R. \& Laslett, G. M. in Advances in Fission-Track Geochronolgy (eds Van den haute, P. \& De Corte, F.) 99-112 (Kluwer-Academic, 1998)

22. Rahn, M. K., Brandon, M. T., Batt, G. E. \& Garver, J. I. A zero-damage model for fission-track annealing in zircon. Am. Mineral. 89, 473-484 (2004).

23. Magoon, L. B. Present-day geothermal gradient, geologic studies of the lower Cook Inlet Cost No. 1 Well, Alaska outer continental shelf. US Geol. Surv. Bull. 1596, 41-46 (1986).

24. Johnsson, M. J., Pawlewicz, M. J., Harris, A. G. \& Valin, Z. C. Vitrinite reflectance and conodont color alteration index data from Alaska: Data to accompany the thermal maturity map of Alaska. USGS Open-File Report 92-409 (1992).

25. Kamp, P. J. J., Green, P. F. \& White, S. H. Fission track analysis reveals character of collisonal tectonics in New Zealand. Tectonics 8, 169-195 (1989).

26. Garver, J. I. \& Kamp, P. J. J. Integration of zircon color and zircon fission-track zonation patterns in orogenic belts: Application to the Southern Alps, New Zealand. Tectonophysics 349, 203-219 (2002).

27. Garver, J. I. Etching zircon age standards for fission-track analysis. Radiat. Meas $37,47-53$ (2003).
28. Brandon, M. T. Decomposition of fission-track grain-age distributions. Am. J. Sci. 292, 535-564 (1992).

29. Fletcher, H. J. \& Freymueller, J. T. New GPS constraints on the motion of the Yakutat block. Geophys. Res. Lett. 26, 3029-3032 (1999).

\section{Acknowledgements}

We thank collaborators of the STEEP project for their help during field work and fruitful discussions. We also thank G. Gehrels and V. Valencia for their guidance on $\mathrm{U} / \mathrm{Pb}$ dating. Sample irradiation was facilitated by the Reactor Use Sharing Program (US DOE) to the Oregon State Nuclear Reactor. A review by P. Reiners improved the manuscript significantly. This study was supported by the NSF grants, EAR-0409132 and 0735402

\section{Author contributions}

All authors contributed to the writing and interpretation. Data analysis was carried out by E.E., P.K.Z., J.I.G. and K.D.R., field work by E.E., T.L.P. and K.D.R. and project planning was done by T.L.P., P.K.Z. and K.D.R.

\section{Additional information}

Supplementary information accompanies this paper on www.nature.com/naturegeoscience. Reprints and permissions information is available online at http://npg.nature.com/ reprintsandpermissions. Correspondence and requests for materials should be addressed to E.E. 